○荒尾はるみ，小川恭子，村橋けい子，柳田則之(名大)

小児期の感音難聴の中に進行を示す症例が存在することはよく知られており。特に西侧 生感音難聼はその3 割近くが進行性であると報告されている。1)2）しかし、一側性の進行 生感音難聴については症列も少なくいまだ不明な点が多い。今回，我々は，小児の耐側性 扔よび一側性の感音難㯖症例における聴力推移について比較検討したので報告する。

\title{
I 対象
}

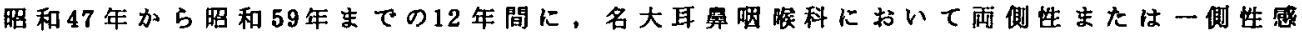
音難聴と診断された15才までの症例の中で，3 年以上の経過を観察し得た症例，両㑡生57 例，一㑡性（盟でないもの）39 例を対象とした。進行の基準としては，厚生省“特発性両 㑑性感音難㯖”研究班の判定基準に基つきき, 接する2 周波数またはそれ以上の周波数で 各々が $15 \mathrm{~dB}$ 以上の進行を示したものとした。

II成績および考按

1 ) 進行頻度おょび性差（表 1 ）

両側は57 例中 18 例 $31.6 \%$ が進行を示したが，一側性は 39 例中 10 例 $10.3 \%$ しか進行を示さず，耐㑡性の方が， 有意差をもってより進行した。両侧性扔よび侧性 とも女性に多い傾向がみられたが，進行群では，两侧 世 8：10,一側性 3：1の男女比であった。
表 1 進行速度および性差

\begin{tabular}{|c|c|c|c|c|}
\hline & & 進行 & 非進行 & 計 \\
\hline 両 & 男 & 8 & 17 & 25 \\
\hline 㑑 & 女 & 10 & 22 & 82 \\
\hline 性 & 計 & 18 & 39 & 57 \\
\hline- & 男 & 8 & 18 & 16 \\
\hline 侧 & 女 & 1 & 22 & 28 \\
\hline 性 & 計 & 4 & 85 & 89 \\
\hline
\end{tabular}

2 ) 家涘歴 (表 2 )

家系内に難㯖者のいる斯合 を家族歴(H)した。両侧生 では, 家族歴(十) 15 例中 8 例の $53.8 \%$ が進行したが， 家歷けの 42 例は10 例 23.8 \%しか進行せず，家蔟歴( の症例が，有意に進行した。 しかし, 一側性では進行し た 4 症例とも家矮歴けであ った。

8 ) 聴力型（表 3 ）

両側生および一側珄とも， 進行，非進行にかかわらず 高音漸傾型，高音急㤠型。 水平型が $7 \sim 8$ 割を占め。 差はなかった。
表 2 家族歴

\begin{tabular}{|c|c|c|c|c|c|c|}
\hline & \multicolumn{3}{|c|}{ 両側伡感音難聴 } & \multicolumn{3}{|c|}{ 一㑡珄感音難僡 } \\
\hline & 家族歴十 & 家族歴一 & 計 & 家族歴+ & 家族歴+ & 計 \\
\hline 進 行 & 8 & 10 & 18 & 0 & 4 & 4 \\
\hline 非進行 & 7 & 82 & 39 & 2 & 88 & 35 \\
\hline 計 & 15 & 42 & 57 & 2 & 87 & 89 \\
\hline
\end{tabular}

表 3 聼力型

\begin{tabular}{|c|c|c|c|c|c|c|}
\hline & \multicolumn{3}{|c|}{ 両㑡栍感音離聴 } & \multicolumn{3}{|c|}{ 一㑡生感音難聴 } \\
\hline & 進 行 & 非進行 & 計 & 進 行 & 非進行 & 計 \\
\hline 低音障害型 & 0 & 1 & 1 & 0 & 5 & 5 \\
\hline 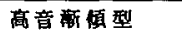 & 6 & 12 & 18 & 1 & 6 & 7 \\
\hline 高音急檠型 & 4 & 4 & 8 & 2 & 8 & 10 \\
\hline 水 平 型 & 6 & 12 & 18 & 1 & 12 & 18 \\
\hline 山 & 0 & 1 & 1 & $\mathbf{0}$ & 1 & 1 \\
\hline 谷 & 0 & 8 & 3 & 0 & 0 & 0 \\
\hline $\operatorname{dip}$ & 0 & 2 & 2 & 0 & 8 & 8 \\
\hline 高渐（反対侧整） & $\mathbf{0}$ & 1 & 1 & & & \\
\hline 高急（反対側需） & 2 & 1 & 3 & & & \\
\hline dip (反対側售) & 0 & 2 & 2 & & & \\
\hline 計 & 18 & 89 & 57 & 4 & 85 & 39 \\
\hline
\end{tabular}


4 ) 進行の状況と時期

(1)難聴の進行には高音域の進行が先行する型と，全周波数にわたって進行する型とが みられた。その内訳は，

高音域進行型：両側性の高音踔害型 12 例中 7 例

全周波数域進行型：両側性の高音障害型 12例中 5 例および水平型全 6 例。

一僋生進行例全 4 例

(2)進行の速度には，階段状進行と經徐進行とがみられた。即ち。

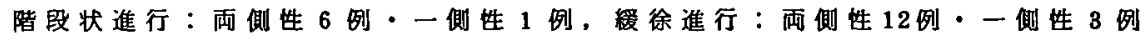
両側性に㧍いて緩徐進行症例は左右同様に進行したが, 階段状進行症例は左右時期 を異にして進行した。その時期峙段状では10耳中 7 耳が, 9 歳から12歳の間で進 行し, 一方楥徐進行では最高18歳でも尚, 進行中の症例が認められた。一側生階段状 進行症例は13歳時に，8 年の間隔をもって突然覀化を認めた。

7 ) 治 療

ステロイドを主体とした治療を行なった。両側性では 9 例中 1 例は前段階まで回復

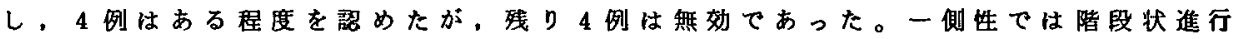
庭例 1 例に施行されたが無奻であった。

8 ) 一 側生の健侧聴力

全症例とも悪化は認めなかった。

III とめ

小児感音難聴，両側性 57 例，一側性 39 例の聴力推移について比較検討した。

1 ) 䍓侧 $31.6 \%$, 一侧性 $10.3 \%$ に進行がられ, 両㑡性の方が有意に進行した。

2 ) 雨側性では, 家系内に難罳者のいる症例の方が有意差をもって進行したが, 一僋性 進行例 4 例とも家族歴がなった。

8) 難聴の進行には，高音域准行と全周波数域進行がみられ，その速度には陼段状進行 と緩徐進行とがられた。
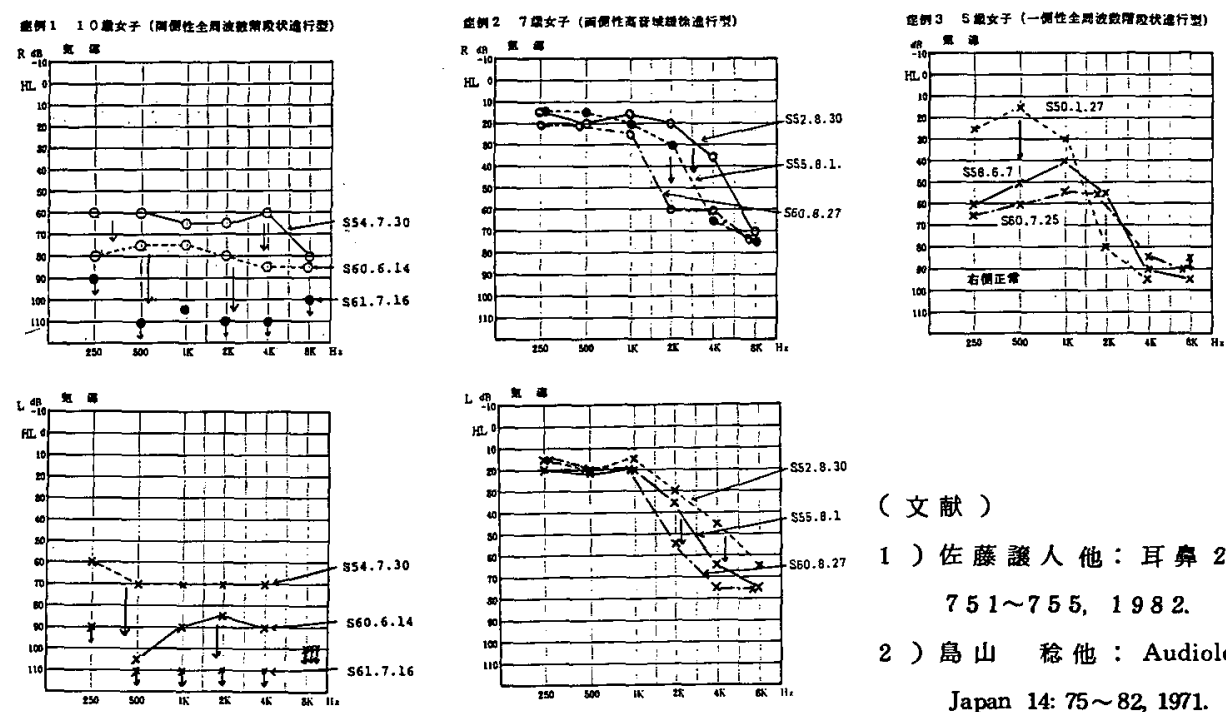

(文献)

1 ) 佐藤譲人他:耳粤 28:

$751 \sim 755,1982$.

2 ) 島山稔他: Audiology.

Japan 14: 75 82, 1971. 